УДК 343.1

DOI https://doi.org/10.32837/pyuv.v0i1(30).541

\author{
Д. О. Шумейко \\ orcid.org/0000-0002-3185-9956 \\ кандидат юридичних наук, \\ викладач кафедри кримінального процесу \\ Національної академії внутрішніх справ
}

\title{
ПОВІДОМЛЕННЯ ПРО ПІДОЗРУ ЯК УМОВА ЗДІЙСНЕННЯ СПЕЦІАЛЬНОГО ДОСУДОВОГО РОЗСЛІДУВАННЯ
}

Постановка проблеми. Повідомлення про підозру - важлива частина досудового розслідування, ця процесуальна дія є певним підсумком результатів роботи органів досудового розслідування щодо встановлення факту вчинення злочину та причетності конкретної особи до цього злочину. Якщо повідомлення про підозру не може бути вручене особі, оскільки місцезнаходження її не встановлене, КПК України передбачає особливий процесуальний механізм, що включає низку заходів, які передбачають дії сторони обвинувачення для інформування такої особи. Для спеціального кримінального провадження така ситуація є типовою.

Аналіз останніх наукових публікацій свідчить про увагу науковців до досліджуваної тематики. Питання нормативного регулювання та практики застосування спеціального досудового розслідування вивчались Ю.П. Аленіним, І.В. Басистою, Є.Г. Бендерською, Г.П. Власовою, Д.Т. Арабулі, В.І. Галаганом, І.В. Гловюк, С.А. Головатим, Ю.М. Грошевим, О.М. Дроздовим, О.В. Захарченком, I.І. Сливичем, А.В. Кіщенковим, О.П. Кучинською, О.В. Маленком, В.Т. Маляренком, Г.В. Матвієвською, О.О. Нагорнюком-Данилюком, В.В. Онопенком, Р.Г. Пєсцовим, М.А. Погорецьким, В.О. Попелюшком, О.Ю. Татаровим, В.М. Трофименком, В.М. Трубніковим, Т.В. Трубніковою, Л.Д. Удаловою, С.Л. Шаренко, Р.М. Шехавцовим, А.В. Шевчишеним, О.Г. Шило, О.Г. Яновською та іншими.

Метою цієї роботи $\epsilon$ аналіз нормативного регулювання та наукових підходів щодо ознак підозри, поняття обгрунтованості підозри, особливостей повідомлення про підозру, якщо місцезнаходження особи не встановлене, з'ясування проблем правозастосування та формулювання рекомендацій задля підвищення його якості.

Виклад основного матеріалу. О.В. Капліна визначає ознаки підозри.

1. Підозра може сформуватися тільки після внесення відомостей до ЄРДР, початку кримінального провадження, проведення слідчих (розшукових), негласних (розшукових) та інших процесуальних дій.

2. Підозра може виникнути в осіб, які здійснюють досудове розслідування - слідчого та/або прокурора. Це положення має важливе значення, оскільки припущення про вчинення кримінального правопорушення певною особою, яке виникло в потерпілого, його представника, заявника, свідка, особи, яка здійснила законне затримання в порядку ст. 207 КПК України, тощо не тягнуть за собою правових наслідків, та можуть бути підставою для висунення та перевірки слідчих версій стороною обвинувачення.

3. Підозра завжди суб'єктивна, оскільки виникає на підставі внутрішнього переконання слідчого та/або прокурора, яке формується відповідно до зібраних у кримінальному провадженні доказів.

4. Підозра - це ймовірне судження, припущення, попередній висновок про причетність конкретної особи до вчинення кримінального правопорушення. У разі отримання нових доказів раніше повідомлена підозра може бути змінена. Це відрізняє підозру від підсумкового висновку слідчого чи прокурора про винуватість особи, який формулюється в обвинувальному акті та має бути з точки зору сторони обвинувачення обгрунтованим, достовірним та остаточним. Саме тому обвинувачення, відповідно до п. 13 ч. 1 ст. 3 КПК України, є твердженням про вчинення певною особою діяння, передбаченого Законом України про кримінальну відповідальність, висунуте в порядку, встановленому КПК України. Підозра не може бути твердженням, її сутність полягає в тому, що це тільки припущення, яке необхідно перевірити під час нового етапу досудового розслідування, який наступає після повідомлення про підозру конкретної особи.

5. Підозра має бути обгрунтованою, оскільки закон вимагає, що особа обов'язково повідомляється про підозру передусім за наявності достатніх доказів для їі підозри у вчиненні кримінального правопорушення (п. 3 ч. 1 ст. 276 КПК України). Якщо про підозру повідомляють особу в разі обрання щодо неї запобіжного заходу, в клопотанні слідчого також уже мають бути такі достатні докази, оскільки КПК України встановлює, що підставою для застосування запобіжного заходу є наявність обгрунтованої підозри у вчиненні особою кримінального право порушення (ч. 2 ст. 177 КПК України). Підставою для ймовірного висновку 
про причетність особи до вчинення злочину та повідомлення особи про підозру є також сам факт затримання особи на місці вчинення кримінального правопорушення чи безпосередньо після його вчинення (п. 1 ч. 1 ст. 276 КПК України). Цим фактом і обгрунтовується виникнення припущення про вчинення кримінального правопорушення певною особою.

6. Підозра має бути формалізована у вигляді процесуального документа - повідомлення про підозру, який складається відповідно до вимог ст. 277 КПК України. Сама собою підозра без її юридичного оформлення є тільки гіпотезою та не породжує правових наслідків.

7. Підозра як обгрунтоване припущення про вчинення кримінального правопорушення певною особою має бути перевірена під час кримінального процесуального доказування для її спростування або підтвердження та трансформації в обвинувальне твердження, що знайде своє відображення в обвинувальному акті. Причому підозра не має бути єдиним припущенням, яке у свідомості слідчого чи прокурора перетворюється на презумпцію винуватості особи. Вона має бути сформульована та перевірена в сукупності зі всіма доказами, разом із версією про невинуватість особи, про непричетність їі до вчинення кримінального правопорушення, що повністю відповідатиме правовому змісту такої засади кримінального провадження, як презумпція невинуватості.

8. Підозра не може грунтуватися на доказах, отриманих незаконним шляхом. Це випливає із загальної засади законності кримінального провадження (ч.ч. 1, 2 ст. 9 КПК України), а також прямо передбачено в ч. 3 ст. 17 КПК України.

9. Підозра-цеобов' язковийетапкримінального провадження, зокрема стадії досудового розслідування, оскільки саме з моменту повідомлення про підозру у вчиненні кримінального правопорушення починається притягнення особи до кримінальної відповідальності (п. 14 ч. 1 ст. 3 КПК України).

10. Структурні елементи, які входять до підозри та формалізуються в повідомленні про підозру, мають повністю відтворюватися в обвинувальному акті. У разі виникнення підстав для повідомлення про нову підозру або при зміні первинної підозри слідчий, прокурор зобов'язані знову вручити особі повідомлення про підозру з виконанням вимог ст. 278 КПК України. Звичайно, фактичні дані, які входять до змісту підозри, можуть не мати фотографічної ідентичності з обвинувальним актом, тобто можуть бути значно вужчі, ніж ті, що слідчий чи прокурор вкажуть в обвинувальному акті. Навіть закон надає таку можливість, оскільки відповідно до п. 6 ч. 1 ст. 277 КПК України до повідомлення належить стислий виклад фактичних обставин кримінального правопорушення, у вчиненні якого підозрюється особа [1, с. 240-241].
На відміну від обвинувачення, підозра не $є$ твердженням про вчинення особою кримінального правопорушення, а тільки припущенням, яке обгрунтовується і підтверджується доказами, зібраними у встановленому законом порядку. Підозра є попереднім висновком та основою для обвинувачення. Набуття особою статусу підозрюваного, крім переліку додаткових прав, має суттєві правові наслідки для такої особи, тому дотримання вимог, що визначають випадки повідомлення про підозру, її зміст, порядок вручення має суттєве значення для подальшої реалізації процесуальних дій і заходів, які можливі лише щодо підозрюваного.

КПК України передбачає загальний порядок повідомлення про підозру (ст. 276 КПК України), зміст письмового повідомлення про підозру (ст. 277 КПК України), порядок вручення письмового повідомлення про підозру (ст. 278 КПК України) та інші заходи, пов'язані зі здійсненням цієї процесуальної дії.

Відповідно до вимог ст. 297-1 КПК України, питання про здійснення спеціального досудового розслідування (СДР) слідчий суддя розглядає, якщо особа вже набула процесуального статусу підозрюваного під час здійснення досудового розслідування у звичайному порядку.

Законодавець визначив низку механізмів, які дають змогу здійснити повідомлення про підозру особі, яка ухиляється або тільки від цієї процесуальної дії, або взагалі від участі у провадженні. Спосіб здійснення повідомлення про підозру особі, яка ухиляється від особистого вручення їй повідомлення єдиний і для провадження, яке надалі відбуватиметься у загальному порядку, і для провадження, яке здійснюватиметься у формі СДР.

Якщо особа переховується від органів слідства та суду, ухиляється від явки за викликом, місцеперебування ï не встановлене, орган досудового розслідування позбавлений змоги особисто вручити повідомлення такій особі. У таких випадках вживається комплекс дій, які передбачені ст.ст. 42, 111, 135, 278 та главою 11 КПК України, що є підтвердженням виконання обов'язків уповноважених органів щодо дотримання порядку повідомлення особи про підозру.

Ч. 1 ст. 42 КПК України передбачає такі способи набуття особою статусу підозрюваного:

- повідомлення про підозру у порядку ст. 276-279 КПК України;

- затримання особи за підозрою у вчиненні кримінального правопорушення;

- вжиття заходів, передбачених КПК України для вручення повідомлень, якщо письмове повідомлення про підозру не вручено особі внаслідок не встановлення їі місцезнаходження.

Останнє підтверджується даними про виконання передбачених законом дій уповноваженими 
органами щодо складання такого повідомлення та вжиття заходів задля того, щоб особа, щодо якої складене повідомлення, його отримала.

Якщо для кримінальних проваджень, в яких повідомлення про підозру вручається особі, місцезнаходження якої відоме, тобто безпосередньо, типовими проблемами та недоліками є повідомлення про підозру неналежним суб'єктом, відсутність відмітки про вручення, незазначення дати вручення, нероз'яснення прав підозрюваного у змісті повідомлення та ін., то для кримінальних проваджень, в яких особу повідомляють про підозру у спосіб, передбачений для випадків, коли 1іi місцезнаходження не встановлено, типовим недоліком, що призводить до відмови у здійсненні СДР, є недоведеність стороною обвинувачення факту повідомлення особи про підозру.

Законодавець не визначає вимоги щодо змісту діяльності сторони обвинувачення, що може свідчити про достатність та ефективність дій, які вживались для повідомлення, передбачений тільки певний перелік дій, які зобов'язані вжити уповноважені суб'єкти.

Розглянемо кілька прикладів правозастосовної практики, які ілюструють різне бачення слідчих суддів щодо доведеності належного вручення повідомлення про підозру (ухвали слідчих суддів за результатами розгляду клопотань про здійснення СДР).

Так, в ухвалах зазначається: ....На неодноразові виклики підозрюваний ОСОБА_1 до органу досудового розслідування жодного разу не з'явився та про поважні причини своєї неявки не повідомив. Відсутність інформації про фактичне місце перебування підозрюваного ОСОБА_1 позбавило орган досудового розслідування можливості вручити йому особисто письмове повідомлення про підозру від 19.03.2018 року у день його складання, а тому зазначене повідомлення про підозру відповідно до вимог ч. 1 ст. 278, ст.ст. 111, 135 КПК України направлено у спосіб, передбачений для вручення повідомлень, а саме надіслано поштою за адресою реєстрації та останнього відомого місця проживання підозрюваного ОСОБА_1, а також до відповідної житлово-експлуатаційної організації [2];

... 3 матеріалів, доданих слідчим до клопотання, та зі змісту апеляційної скарги вбачається, що виконати вимоги ст.ст. 135, 278 КПК України в частині вручення повідомлення про підозру ОСОБА_4 органу досудового розслідування не видалося за можливе. Крім того, з аналізу наданих до суду апеляційної інстанції матеріалів взагалі не вбачається, що стороною обвинувачення вжито будьякі заходи, спрямовані на виконання вказаних вимог закону. Зазначене повідомлення про підозру взагалі не направлялося засобами поштового зв'язку чи електронною поштою, оскільки матеріали провадження не містять жодних доказів тако- го направлення. Формальне посилання стороною обвинувачення на розпорядження Кабінету Міністрів України від 10.01.2002 р. щодо обмеженої діяльності УДППЗ «Укрпошта» могло б мати місце лише в частині обгрунтування причин направлення вказаного повідомлення ОСОБА_4 іншими засобами зв'язку, в тому числі поштовими, які здійснюють свою діяльність на території України та на які не поширюється вказане розпорядження Кабінету Міністрів України. Однак вказаних дій стороною обвинувачення не виконано.

За таких обставин колегія суддів доходить висновку, що слідчим суддею відповідно до вимог закону правильно зазначено, що ОСОБА_4 не є підозрюваним у цьому кримінальному провадженні, оскільки органом досудового розслідування не виконано вимоги, спрямовані на вжиття заходів щодо направлення останньому повідомлення про підозру, а матеріали клопотання не містять підтвердження такого направлення. Як видається зі змісту клопотання, ОСОБА_4 проживає на території м. Донецьк. 3 огляду на те, що сторона обвинувачення дотримується позиції про неможливість здійснення зв'язку з вказаним населеним пунктом, оскільки УДППЗ «Укрпошта» не здійснює свою діяльність на зазначеній територіі, в органу досудового розслідування взагалі відсутні підстави стверджувати, що особа переховується 3 метою ухилення від кримінальної відповідальності, оскільки стороною обвинувачення взагалі не вжито заходів для повідомлення її про необхідність з' явитись до слідчих органів та вручення повідомлення про підозру.

Матеріали клопотання містять дані, що ОСОБА_4 мав сторінку у всесвітній мережі «Інтернет», що давало змогу, зокрема, направити повідомлення про підозру ОСОБА_5 і в такий спосіб [3];

20 березня 2018 р. у кримінальному провадженні складено письмове повідомлення про змінену підозру громадянину України ОСОБА_1 у вчиненні злочинів, передбачених ч. 3 ст. 109 , ч. 2 ст. 110 та ч. 1 ст. 111 КК України. У зв язку з відсутністю поштового з'єднання між материковою частиною України та тимчасово окупованою територією півострова, письмове повідомлення про підозру було відскановано та відправлено на офіційну електронну пошту «ЦИК Республики Крым» за адресою ikrk2014@mail.ru (протокол огляду від 21.03.2018 р.) [4].

Наведені та інші приклади свідчать, що слідчі судді особливу увагу приділяють дослідженню обставин, що підтверджують активність сторони обвинувачення щодо вручення повідомлення про підозру.

У Методичних рекомендаціях щодо процесуального керівництва спеціальним досудовим розслідуванням зазначено, що в разі неможливості безпосереднього вручення слідчим, прокуро- 
ром повідомлення про підозру особі в день його складання КПК України містить бланкетні норми (ч. 1 ст. 278, ст. 111, ст. 112), які відсилають до загального порядку виклику особи для участі у процесуальній дії (ст.ст. 133, 135 та ін. глави 11 КПК України). Такий порядок не вимагає одразу вручення цього повідомлення особі, щодо якої воно складене, якщо його неможливо їй вручити через невстановлення органом досудового розслідування місця її знаходження.

Головне, щоб зміст такого повідомлення відповідав вимогам ст. 277 КПК України і було документально підтверджено, що орган досудового розслідування вживав заходів для встановлення місцезнаходження цієї особи, але позитивних результатів вони не дали. 3 моментом появи відповідних документів у кримінальному провадженні (зауважимо, що їх кількість, характер і зміст залежить від конкретної слідчої ситуації) пов'язується й момент набуття особою офіційного статусу підозрюваного.

Констатація наявності цих документів має оціночний характер і здійснюється слідчим або прокурором за їх внутрішнім переконанням з урахуванням інших правил ст. 94 КПК України. Щодо заходів для встановлення місцезнаходження особи, стосовно якої складено повідомлення про підозру, такими вважаються проведені з відповідною метою слідчі та негласні слідчі (розшукові) дії (допити свідків, які знають цю особу та можуть володіти інформацією про її місцеперебування; огляди і обшуки житла, іншого володіння цієї особи та інших осіб, якщо є дані про її перебування в певних житлових та інших приміщеннях (в схованках на місцевості тощо); накладення арешту на кореспонденцію, ㄲï огляд і виїмка тощо), тимчасовий доступ до предметів і документів, витребування та отримання від органів державної влади і місцевого самоврядування документів і відомостей, інші процесуальні дії.

Правильний вибір компетентних установ й органів, звернення до яких забезпечить сторону обвинувачення необхідними їй достовірними та допустимими для доказування в суді фактичними даними, залежить від статусу особи, стосовно якої складено повідомлення про підозру (іноземець, біженець, внутрішньо переміщена особа тощо). У таких ситуаціях потрібно використовувати відомості Міністерства закордонних справ України, органів Державної прикордонної служби України, Служби безпеки України, Національної поліції, Державної міграційної служби України, Міністерства соціальної політики України, органів місцевого самоврядування, які формують інформаційні бази даних або ведуть певні обліки відповідно до Законів України «Про свободу пересування та вільний вибір місця проживання в Україні», «Про правовий статус іноземців та осіб без громадянства», «Про біженців та осіб, які потребують додаткового або тимчасового захисту», «Про основи соціального захисту бездомних осіб і безпритульних дітей», «Про Єдиний державний демографічний реєстр та документи, що підтверджують громадянство України, посвідчують особу чи її спеціальний статус», "Про соціальні послуги» тощо [5, с. 16-18].

Відповідно до ч. 2 ст. 297-4 КПК України, вирішуючи питання про здійснення СДР, слідчий суддя зобов' язаний врахувати наявність достатніх доказів для підозри особи, щодо якої подано клопотання про здійснення СДР.

Законодавець не роз'яснює поняття достатності доказів для підозри, тому це питання часто неоднаково вирішується на практиці.

У практичній площині законодавча вимога щодо наявності достатніх доказів для підозри особи, щодо якої подано клопотання про здійснення СДР, у вчиненні кримінального правопорушення пов' язаназдоказуваннямобгрунтованостіпідозри.

M.А. Погорецький зазначає, що законодавець передбачив широку сферу застосування стандарту доказування «обгрунтованапідозра» в процесі прийняття низки процесуальних рішень, зокрема про:

- вжиття заходів забезпечення кримінального провадження (п. 1 ч. 3 ст. 132 КПК), у тому числі при вирішенні питання про арешт майна (п. 3 ч. 2 ст. 173 КПК);

- обрання запобіжних заходів (ч. 2 ст. 177 ; п. 1 ч. 1 ст. 194 КПК);

- проведення окремих негласних (слідчих) розшукових дій (ч. 1 ст. 269-1 КПК).

Системне тлумачення норм кодексу також дає змогу стверджувати, що стандарт доказування «обгрунтована підозра» має виконуватися в процесі повідомлення особи про підозру відповідно до ст. 276 КПК [6].

Підтримуючи цю позицію, додамо до цього переліку ухвалення рішення про здійснення СДР (ч. 2 ст. 297-4 КПК України).

M.А. Погорецький на основі аналізу та узагальнення правових позицій ЄСПЛ та національної правозастосовної практики визначає критерії обгрунтованості підозри.

Стандарт доказування «обґрунтована підозра» вважається досягнутим, якщо фактів та інформації достатньо, аби переконати об'єктивного спостерігача в тому, що відповідна особа могла вчинити кримінальне правопорушення.

Обгрунтованість підозри може встановлюватися тільки щодо діяння, яке підпадає під ознаки правопорушення за законом про кримінальну відповідальність.

Обгрунтованість підозри не може встановлюватися in abstracto або грунтуватися на суб'єктивних припущеннях, а має підкріплюватися конкретними доказами в кримінальному провадженні. 
Стандарт доказування «обґрунтована підозра» не передбачає, що уповноважені органи мають оперувати доказами, достатніми для пред'явлення обвинувачення чи ухвалення обвинувального вироку, що пов'язано з меншою мірою ймовірності, необхідною на ранніх етапах кримінального провадження для обмеження прав особи.

Стандарт доказування "обгрунтована підозра» має динамічний характер, тобто з плином часу така підозра в учиненні кримінального правопорушення не може бути самостійною підставою для продовжування обмеження прав особи, мають бути наведені відповідні й достатні підстави (ризики), підкріплені доказами [6].

Визначення випадків, коли законодавець вимагає доведення обгрунтованості підозри в межах згаданої категорії «стандарт доказування» та визначення критеріїв обгрунтованості підозри сприяє формуванню уніфікованого понятійного апарату, однакового розуміння закону, едності правозастосовної практики.

Висновок. Зміст дій сторони обвинувачення в разі неможливості вручення письмового повідомлення про підозру особі внаслідок невстановлення її місцезнаходження становить: 1) дотримання вимог ст. 277 КК України; 2) вжиття заходів щодо встановлення місцезнаходження особи та ïх результати; 3) виконання дій, які передбачені ст.ст. 42, 111, 135, 278 та главою 11 КПК України.

Достатність доказів для підозри особи, щодо якої подано клопотання про здійснення спеціального досудового розслідування як умову для ухвалення відповідного рішення, ми пропонуємо розглядати як дані і відомості щодо встановлення факту учинення злочину та ймовірної причетності конкретної особи до цього злочину, що також відповідає визначеній у позиціях ЄСПЛ формулі поняття «обгрунтована підозра» - «існування фактів та інформації, які можуть переконати об'єктивного спостерігача, що особа, про яку йдеться, могла скоїти правопорушення».

Визначено та класифіковано ознаки повідомлення про підозру у спеціальному кримінальному провадженні: процесуальні (внесення відомостей до СРДР, підтвердження виконання дій щодо вручення повідомлення про підозру особі місцезнаходження якої не встановлено); кримінально-правові, або матеріальні (зазначення статті (частини статті) закону України про кримінальну відповідальність, що визначені у ч. 2 ст. 297-1 КПК України, повноліття особи); формалізовані (процесуальний документ - повідомлення про підозру); суб’єктні (слідчий, прокурор).

\section{Jimepamypa}

1. Капліна О.В. Підозра у кримінальному провадженні: поняття, ознаки, сутність. Юридичний часопис Національної академії внутрішніх справ. 2013. № 1. C. 238-242.

2. Ухвала Печерського районного суду м. Києва від 9 вересня 2019 р. Справа № 757/45541/19-к. URL: http://reyestr.court.gov.ua/Review/84245968

3. Ухвала Колегії суддів судової палати з розгляду кримінальних справ Апеляційного суду міста Києва від 13 червня 2017 р. Справа № 11-сc/796/2543/2017. URL: http://www.reyestr.court.gov.ua/Review/67257170.

4. Ухвала Херсонського міського суду Херсонської області від 2 вересня 2019 р. Справа № 766/16638/19. H/п 1-кс/766/12758/19. URL: http://reyestr.court. gov.ua/Review/84003027

5. Методичні рекомендації щодо процесуального керівництва спеціальним досудовим розслідуванням. Академія прокуратури України. Схвалено протоколом засідання науково-методичної ради від 25 травня 2017 р. № 4. Київ, 2017. 65 с.

6. Погорецький М. «Обгрунтована підозра»: непізнаний феномен українського кримінального процесу. Закон і бізнес. № 10 (1412) 16.03-22.03.2019. URL: https://zib.com.ua/ua/136819-yak_minimum_5 kriteriiv_obruntovanosti_pidozri_mae_vrahovuva.html 


\section{Анотація}

Шумейко Д. О. Повідомлення про підозру як умова здійснення спеціального досудового розслідування. Стаття.

Розглянуто процесуальний порядок та особливості повідомлення про підозру особам, місцезнаходження яких не встановлене, визначено та класифіковано ознаки повідомлення про підозру в спеціальному кримінальному провадженні, охарактеризовано наукові підходи до визначення ознак підозри, критеріїв обгрунтованості підозри, стандарту доказування «обгрунтована підозра». 3' ясовано, що, на відміну від обвинувачення, підозра не є твердженням про вчинення особою кримінального правопорушення, а тільки припущенням, яке обгрунтовується і підтверджується доказами, зібраними у встановленому законом порядку. Підозра $\epsilon$ попереднім висновком та основою для обвинувачення. Набуття особою статусу підозрюваного, крім переліку додаткових прав, має суттєві правові наслідки для такої особи, тому дотримання вимог, що визначають випадки повідомлення про підозру, їі зміст, порядок вручення, має суттєве значення для подальшої реалізації процесуальних дій і заходів, які можливі лише щодо підозрюваного. Визначено, що законодавець не визначає вимоги щодо змісту діяльності сторони обвинувачення, що може свідчити про достатність та ефективність дій, які вживались для повідомлення, передбачений тільки певний перелік дій, які зобов'язані вжити уповноважені суб'єкти. Зроблено висновок, що зміст дій сторони обвинувачення в разі неможливості вручення письмового повідомлення про підозру особі внаслідок невстановлення ï місцезнаходження становить: 1) дотримання вимог ст. 277 КК України; 2) вжиття заходів щодо встановлення місцезнаходження особи та їх результати; 3) виконання дій, які передбачені ст.ст. 42 , $111,135,278$ та главою 11 КПК України. Достатність доказів для підозри особи, щодо якої подано клопотання про здійснення спеціального досудового розслідування як умову для ухвалення відповідного рішення, ми пропонуємо розглядати як дані і відомості щодо встановлення факту учинення злочину та ймовірної причетності конкретної особи до цього злочину, що також відповідає визначеній у позиціях Європейського суду з прав людини формулі поняття «обгрунтована підозра» - «існування фактів та інформації, які можуть переконати об'єктивного спостерігача, що особа, про яку йдеться, могла скоїти правопорушення».

Ключові слова: повідомлення про підозру, підозра, спеціальне досудове розслідування, спеціальне кримінальне провадження, обгрунтованість підозри.

\section{Summary}

Shumeiko D. O. Notification of suspicion as a condition for conducting a special pre-trial investigation. Article.

The procedural procedure and peculiarities of the report of suspicion to persons whose location is not established, the signs of the notification of suspicion in special criminal proceedings are considered, scientific approaches to determination of signs of suspicion, criteria of validity of suspicion, standard of proof are characterized. It has been found that, unlike the prosecution, the suspicion is not an allegation of a criminal offense, but only an assumption that is substantiated and supported by evidence collected in accordance with the procedure established by law. Suspicion is the preliminary conclusion and basis for the prosecution. The acquisition of a suspect's status, in addition to the list of additional rights, has significant legal consequences for such a person, so compliance with the requirements that determine cases of notification of suspicion, its content, the order of service is essential for the further implementation of procedural actions and measures that are possible only with respect to the suspect. It is determined that the legislator does not specify requirements for the content of the activity of the prosecution party, which may testify to the sufficiency and effectiveness of the actions taken for the notification, only a certain list of actions required by the authorized subjects is provided. It is concluded that the content of the actions of the prosecution party in case of failure to serve a written notice of suspicion of the person due to failure to establish his location is: 1) compliance with the requirements of Art. 277 of the Criminal Code of Ukraine; 2) taking measures to determine the location of the person and their results; 3 ) implementation of the actions provided for in Art. Art. 42, 111, 135, 278 and Chapter 11 of the CPC of Ukraine. Sufficiency of Evidence for Suspicion of a Person Requested for Special Pre-trial Investigation as a Requirement for Adoption of a Decision, we propose to consider as data and information about the establishment of a crime and the alleged involvement of a specific person, which is also in line with the European position of the human rights court of the notion of reasonable suspicion - "the existence of facts and information that can convince an objective observer that the person in question could and commit offenses".

Key words: suspicion reports, suspicion, special pre-trial investigation, special criminal proceedings, validity of suspicion. 